\title{
C18 Sep-Pak Extractable Dissolved Organic Copper Related to Hydrochemistry in the North-west Mediterranean
}

\author{
Mohamed A. EL Sayed ${ }^{a}$ and Alain Aminot ${ }^{b}$ \\ ${ }^{a}$ National Institute of Oceanography and Fisheries, Alexandria, Egypt \\ ${ }^{\mathrm{b}}$ IFREMER-Brest, BP 70, 29280, Plouzané, France
}

\begin{abstract}
:
Extractable organic copper using C18 Sep-Pak cartridges was investigated in seawater after laboratory experiment showed that the (C18 Sep-Pak) cartridges were reliable, in open and coastal waters with normal levels of dissolved organic carbon, for the separation of a specific fraction of organo-copper complexes.

Given that the Sep-Pak cartridges retain the hydrophobic fraction of the dissolved organic matter, this extraction technique was applied for studying the characteristics of this particular hydrophobic dissolved organic copper fraction (hDOCu) in the north-western Mediterranean waters. Surface distribution of hDOC is influenced by organic matter input from the river Rhone and its estuary as well as the physical processes affecting the primary productivity such as coastal upwelling. By correlating hDOCu concentrations with total dissolved copper and other hydrochemical data such as salinity and dissolved organic carbon, it was possible to examine the behaviour of hDOCu in the water masses of different sources and ages.

Marine organic matter has been shown to have high complexing capacity. Productive superficial and intermediate waters as well as deep waters showed relatively high and comparable complexing capacity indicating that old organic matter may have strong complexing sites.
\end{abstract}

Keywords: copper compounds; dissolved organic matter; seawater; Mediterranean sea 


\section{INTRODUCTION}

There is an increasing evidence that the biogeochemical cycling of a certain number of trace elements is greatly controlled by the interaction with organic matter (Boyle et al., 1977; Bruland, 1989; Paulson, 1991; Paulson et al., 1994a, 1994b). However, the extremely low concentration of dissolved trace metals and complexing organic ligands, relative to the very high salt content in seawater, have rendered the study of dissolved metal organic complexes exceedingly tedious and very delicate.

The need to identify the nature of the organic ligands implies the use of non violent techniques of separation and concentration which do not denaturate the complexes. Solvent extraction (Jeffrey, 1970), adsorption on inorganic surfaces such as charcoal (Kerr and Quinn, 1980) and synthetic organic polymers such as Amberlite and Sephadex resins (Kremling et al., 1981; Hirose et al., 1982) have been shown to suffer from serious problems such as high level of contamination, limited separation capacity and low recovery.

The C18 Sep-Pak extraction (C18 SPE) technique has been introduced by Mills and Quinn (1981) for the determination and characterization of organic copper complexes. The method is simple and has proven reproducible and free of gross contamination (Mills et al., 1982). Since then, it gained an increasing popularity and has been applied by several authors (Mackey, 1983, 1984, 1985; Mills et al., 1987, 1989; Elbaz-Poulichet et al., 1994).

However, due to the fact that Sep-Pak cartridges seem missing a great deal of the most complexing organic ligands, the technique has been shown to isolate only a relatively small fraction of organic copper from seawater (Donat et al., 1986). Since it is now established that, in practically all estuarine, coastal and even open ocean water, the fraction of the total dissolved copper that is organically complexed is close to $100 \%$ (Van den Berg, 1984; Sunda and Hanson, 1987; Coale and Bruland, 1988), operational separation of organic complexes of copper on the basis of some dominant chemical or physical characteristics would be of considerable interest in speciation studies of dissolved copper. According to Sunda and Hanson (1987), the C18 SPE technique depends on the fact that in any given sample, a direct relationship will exist between various complex species of copper and free cupric ion concentration, provided other important parameters, such as $\mathrm{pH}$, remain constant. In other words, when using the C18 SPE technique, it could be assumed that, when the chemical properties that govern the speciation of dissolved copper are similar, samples should have the same proportion of copper species that adsorb on the SP cartridges. As a corollary, when the extractable proportions differ, waters should have different chemical properties particularly the complexing organic ligands. Retention by the $\mathrm{C} 18$ bonded silica coupled with methanol extraction concerns mostly the non-polar hydrophobic organic matter (Mills et al., 1982; Hanson and Quinn, 1983). Therefore, only the fraction of dissolved copper associated with this class of organic compounds is considered in this study and will be referred to as hydrophobic dissolved organic copper $(\mathrm{hDOCu})$.

The present study was undertaken to measure C18 SP extractable organic copper in the northwestern Mediterranean (Gulf of Lions) and to relate its concentrations to other hydrochemical data, with particular attention to dissolved organic carbon. Additional laboratory experiments showed the reliability of the C18 SPE technique in the operational conditions of application and within the range of environmental characteristics encountered in the investigated natural waters. 


\section{MATERIAL AND METHODS}

Water has been sampled from the northwestern Mediterranean, mainly from the surface layer $(2 \mathrm{~m})$ of the Gulf of Lions and from a vertical profile in the open sea (Fig. 1). Teflon coated Go-Flo bottle (G.O.) was used for sampling along the vertical profile, while surface samples were collected using a teflon coated Niskin bottle provided with silicon rupper spring and fluorinated O-rings. A new stainless steel wire was employed as well as teflon coated steel messengers.

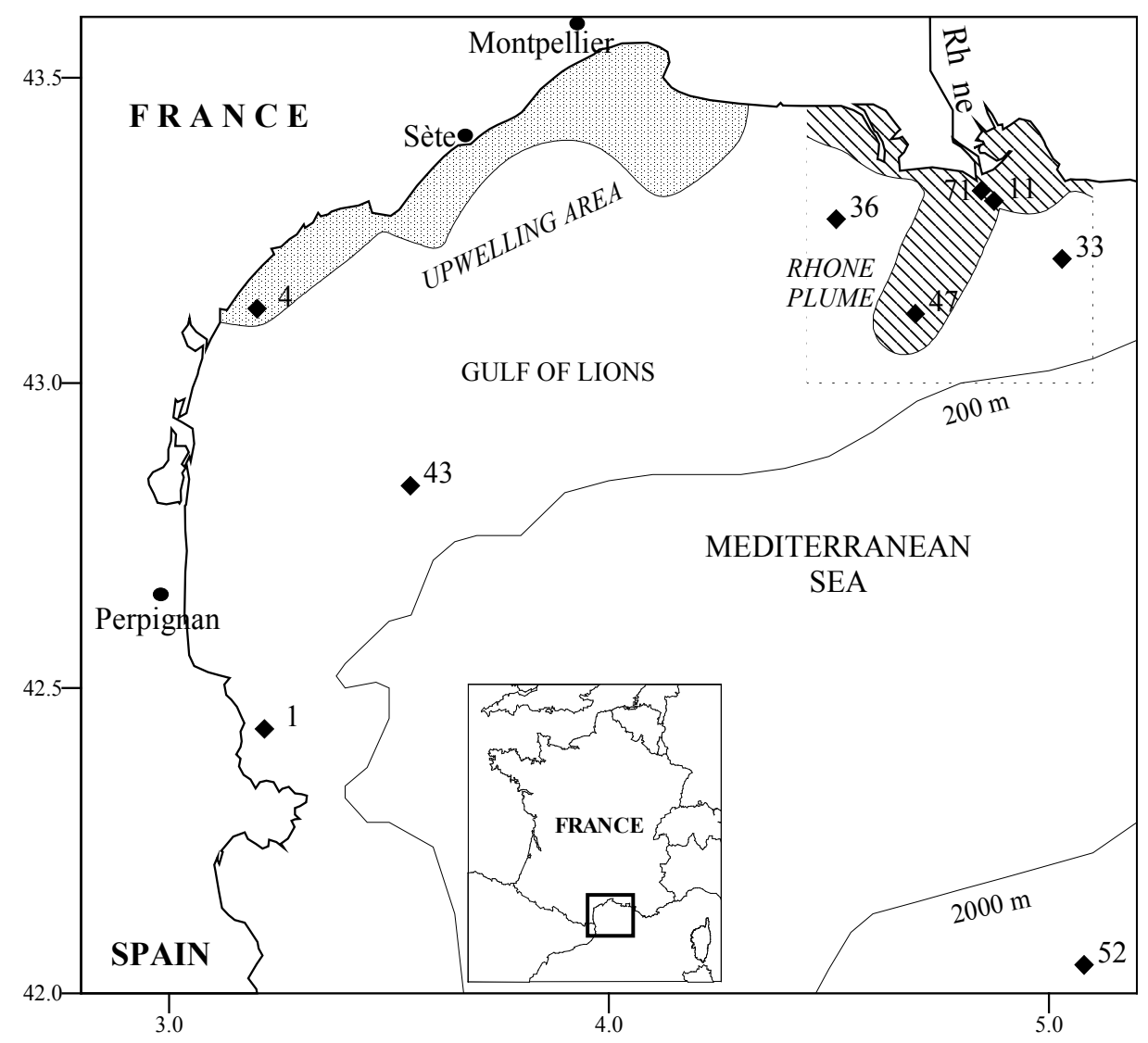

Figure 1. Field study area with location of the sampling stations. The shadowed zones correspond to the upwelling area (salinity $>38.15$ ) and to the Rhone plume (salinity < 37).

Total dissolved copper (TDCu) was analyzed according to Kingston et al. (1978). A particular mount was designed to reduce sample manipulation and minimize contamination (ElSayed, 1988). The C18 SPE technique described by Mills and Quinn (1981) and Mills et al. (1982) was applied for the determination of hDOCu. A slight modification was introduced to avoid technical problems associated with the atomic absorption analysis of the methanol/water extract. The extract was placed in a $5 \mathrm{ml}$ clean Hamilton vial and evaporated to almost dryness under reduced pressure, then $100 \mu \mathrm{l}$ of concentrated nitric acid were added to the residue and the vial was kept for one hour at $60{ }^{\circ} \mathrm{C}$ in the oven. The vial was then cooled and volume was adjusted to $2.5 \mathrm{ml}$ with deionized water. Copper was analyzed using AAS (Varian 1250) equipped with graphite furnace (CRA90) and automatic sample dispenser (AS60). Procedural blank was run in the same way using $50 \mathrm{ml}$ deionized. Six replicate blanks gave average copper concentration of $43 \pm 7 \mathrm{pmol}^{-1}$ in the metanol/water extract and a corresponding detection limit $(3 \times s)$ of $21 \mathrm{pmol}^{-1}$.

Additional determinands, including oceanographic parameters, inorganic nutrients and trace metals (full data in El Sayed et al., 1994), and dissolved organic carbon (DOC) were 
measured simultaneously. The water for determination of dissolved organic carbon was sampled together with nutrients, rapidly filtered through a precombusted Whatman GF/F membrane, stored in a precombusted $50 \mathrm{ml}$ glass bottle with a polyethylene linerless screwcap and immediately placed at $-20{ }^{\circ} \mathrm{C}$ until analyzed at the shore laboratory. DOC was determined by the UV-persulphate oxidation method (Aminot and Kérouel, 1990).

The seawater used in the laboratory experiments was collected from the Bay of Brest (West Brittany, France). Water was collected manually from the surface layer $(-50 \mathrm{~cm})$, in acid cleaned polyethylene containers. Water was immediately filtered in the laboratory through acidprecleaned $0.4 \mu \mathrm{m}$ pore size Nuclepore filters, using a polycarbonate Sartorius filtration system mounted, with a teflon adaptor, on acid-cleaned polypropylene bottles (Nalgene). All the chemicals used were of Merck Suprapur and HPLC grade, and deionized water was supplied from a Milli-Q system (Millipore).

A preliminary laboratory experiment was designed to assess the reproducibility of organic copper extraction in presence and absence of free copper and labile copper complexes. The seawater used in this experiment had a salinity of 34.9, its $\mathrm{pH}$ was 8.04 and it was spiked with

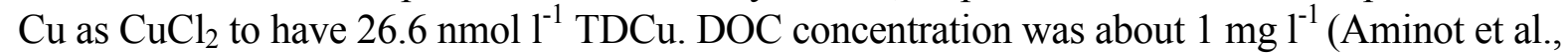
1990). Two series of samples $(250,500$ and $750 \mathrm{ml})$ were processed through preconditioned Sep-Pak cartridges, one series without pretreatment and the other pretreated to remove ionic and labile $\mathrm{Cu}$ complexes. Pretreatment consisted of thorough shaking with $4 \mathrm{ml}$ of the ion exchange resin Chelex-100 (Bio Rad) in the ammonium form for $5 \mathrm{~min}$, then separating the liquid phase. The two series of cartridges were eluted with $5 \mathrm{ml}$ of methanol/water mixture and organic copper was measured in the extract.

\section{RESULTS AND DISCUSSION}

\subsection{Preliminary experiment}

Ion exchange (Chelex-100) resin was used to remove ionic copper and labile complexes from the sample prior to the passage through the Sep-Pak cartridge in order to test whether ionic copper was retained by a process not engaging the organic matter. The results of that experiment (Table 1) show that the concentration of $\mathrm{hDOCu}$ in the sample that was directly processed through the cartridge is about three times the one that had been pretreated with the ion exchange resin ( $22 \%$ against $7 \%$ of the total dissolved copper). While the samples pretreated with the ion exchange resin showed a fairly stable organic copper concentration, the samples processed directly showed a slightly increasing concentration as a function of sample volume (Table 1). Organic copper was increased by $\sim 4 \%\left(\sim 1.1 \mathrm{nmol} \mathrm{l}^{-1}\right)$ when the sample volume increased from 250 to $750 \mathrm{ml}$. The independence of $\mathrm{hDOCu}$ concentration of the sample volume, when the samples were pretreated with the ion exchange resin, indicates the dissociation and screening of the labile organic complexes by the ion exchange resin and subsequent removal of copper ions. The slight increase observed with untreated seawater indicates that some organic copper could be formed during sample processing, however, it would not seriously affect results at concentration levels found in natural water. 
Table 1. Effect of inorganic copper concentration and sample volume processed through cartridge on the extraction of organic copper on Sep-Pak. TDCu $=26.6 \mathrm{nmol}$ l-1.

\begin{tabular}{|c|c|c|c|c|}
\hline \multirow{3}{*}{$\begin{array}{c}\text { Sample } \\
\text { volume } \\
\text { ml }\end{array}$} & \multicolumn{4}{|c|}{ C18 Sep-Pak extractable organic copper } \\
\hline & \multicolumn{2}{|c|}{ without pretreatment } & \multicolumn{2}{|c|}{ pretreated with Chelex-100 } \\
\hline & nmol l' ${ }^{-1}$ & $\% \mathrm{TDCu}$ & nmol l' ${ }^{-1}$ & $\% \mathrm{TDCu}$ \\
\hline 250 & 5.6 & 21 & 1.9 & 7.2 \\
\hline 250 & 5.3 & 20 & 1.8 & 6.6 \\
\hline 500 & 5.8 & 22 & 1.7 & 6.2 \\
\hline 750 & 6.5 & 24 & 1.7 & 6.5 \\
\hline mean $\pm \mathrm{s}$ & $5.8 \pm 0.5$ & $21.8 \pm 1.7$ & $1.8 \pm 0.1$ & $6.6 \pm 0.4$ \\
\hline
\end{tabular}

The results of the experiment also indicate that hydrophobic organic ligands and copper form complexes of different stabilities. Mills and Quinn (1982) have shown that $70 \%$ of the organic copper bonding sites separated by Sep-Pak columns are readily exchangeable (labile) and $30 \%$ undergo a much slower exchange. In this experiment the ion exchange pretreatment was shown to reduce the concentration of organic-copper by about $70 \%$ relative to the concentration measured by direct processing (Table 1). On this basis, the distribution of organic copper as labile and stable complexes would be strikingly similar to that found by Mills and Quinn (1982). Coupling of the Chelex ion exchange and the C18 reversed phase extraction may therefore be used to get interesting information about the nature of the association between trace metals and the natural organic matter.

\subsection{Extractable organic copper in the northwestern Mediterranean}

The strong northwesterly wind that was established in the Gulf of Lions during the sampling period gave rise to coastal upwelling along the coast of the Gulf. In this area, the subsuperficial water brought to the surface from the base of the thermocline (30-40 m depth),

Table 2. Salinity, total dissolved copper (TDCu) and dissolved hydrophobic organic copper (hDOCu) in the northwestern Mediterranean water.

\begin{tabular}{lcccccc}
\hline $\begin{array}{l}\text { Station } \\
\text { number* }\end{array}$ & $\begin{array}{c}\text { Area of } \\
\text { sampling* }\end{array}$ & $\begin{array}{c}\text { Sampling } \\
\text { depth } \\
\text { m }\end{array}$ & $\begin{array}{c}\text { Salinity } \\
\text { (PSS78) }\end{array}$ & $\begin{array}{c}\text { TDCu } \\
\text { nmol I }^{-\mathbf{1}}\end{array}$ & nmol I $^{\mathbf{1}}$ & \% \\
\hline 71 & Rhone mouth & 1 & 7.40 & 28.5 & 6.61 & 23 \\
11 & Rhone plume & 1 & 36.02 & 12.7 & 1.90 & 15 \\
47 & Rhone plume & 1 & 36.23 & 3.2 & 0.69 & 22 \\
36 & Upwelling & 1 & 38.01 & 2.6 & 0.79 & 30 \\
4 & Upwelling & 1 & 38.16 & 3.8 & 0.72 & 19 \\
1 & Gulf of Lions & 1 & 38.09 & 3.1 & 0.52 & 17 \\
33 & Gulf of Lions & 1 & 38.10 & 2.1 & 0.49 & 23 \\
43 & Gulf of Lions & 1 & 38.12 & 2.6 & 0.57 & 22 \\
52 & Open-sea & 1 & 38.24 & 3.2 & 0.31 & 10 \\
52 & Open-sea & 15 & 38.33 & 3.1 & 0.61 & 20 \\
52 & Open-sea & 50 & 38.31 & 1.9 & 0.61 & 33 \\
52 & Open-sea & 200 & 38.50 & 1.6 & 0.41 & 26 \\
52 & Open-sea & 600 & 38.47 & 1.6 & 0.36 & 23 \\
52 & Open-sea & 1000 & 38.46 & 1.6 & 0.31 & 20 \\
\hline
\end{tabular}

* see Figure 1. 
was previously enriched in nutrients and possessed high primary productivity (El Sayed et al., 1994). The distribution pattern of surface temperature and salinity were greatly different from that observed under normal vertical stratification. Distinct water bodies could be differentiated according to their physical and chemical characteristics (detailed description of the hydrological conditions and results of nutrients and trace metals are given in El Sayed et al., 1994).

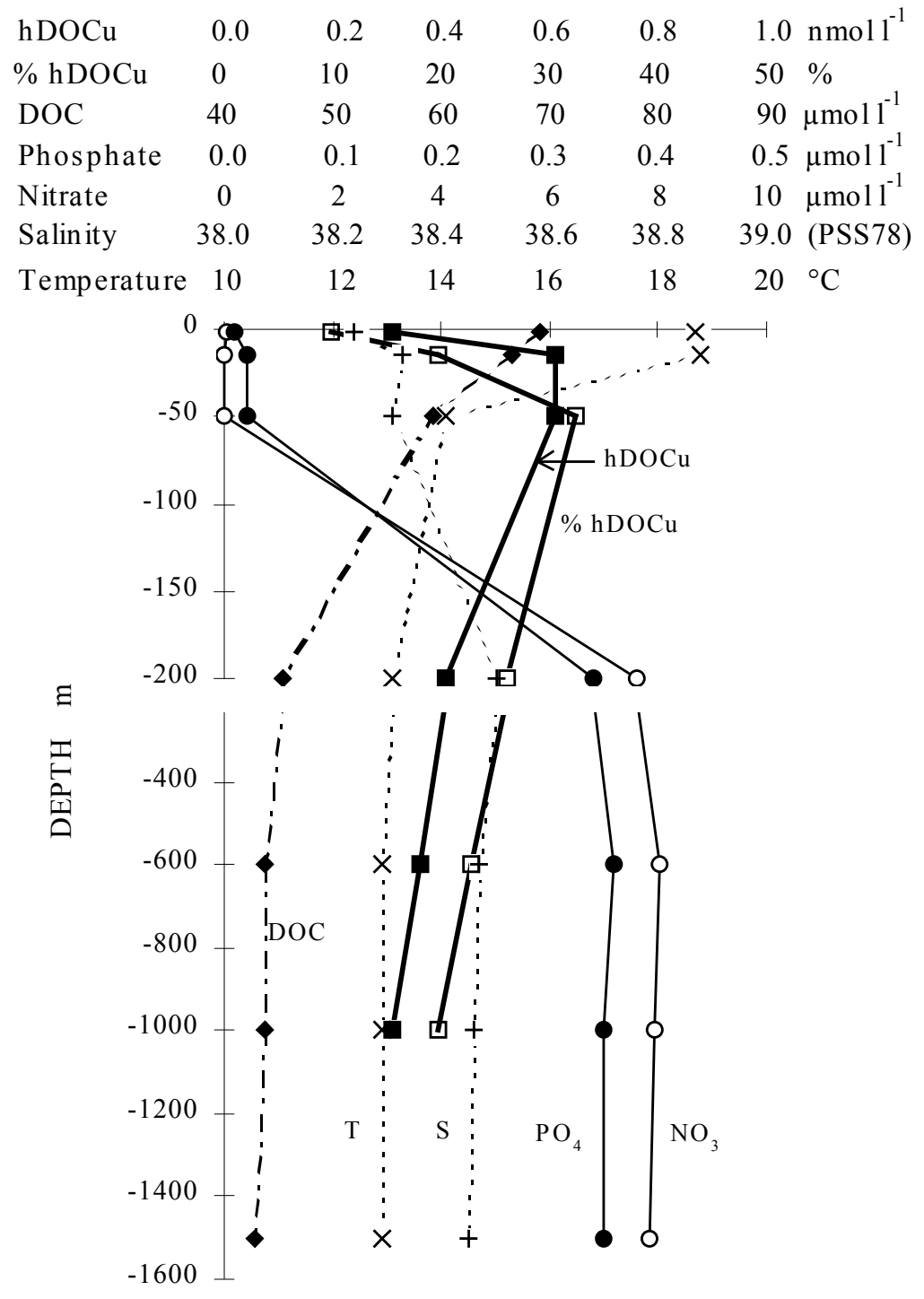

Figure 2. Vertical profile of hydrophobic dissolved organic copper $(\mathrm{hDOCu})$ and other typical oceanographic parameters at the open-sea station in the northwestern Mediterranean.

Results of C18 Sep-Pak extractable organic copper $(\mathrm{hDOCu})$ are presented in Table 2, along with salinity and total dissolved copper. The Sep-Pak extracted organic copper ranged between 10 and $33 \%$ of the TDCu. These values are comparable to those obtained by other authors using the same technique (Hanson, 1981; Hanson and Quinn, 1983; Elbaz-Poulichet et al., 1994). The Rhone river mouth showed the highest concentration followed by the dilution zone of the river plume and offshore waters of the Gulf of Lions. The lowest concentrations were recorded in the open sea surface water. The vertical profile of organic copper, and other main determinands, at the open sea station shows that the percentage of $\mathrm{hDOCu}$ increases from $10 \%$ at the surface to $33 \%$ at $50 \mathrm{~m}$ just below the thermocline and then decreases downwards (Fig. 2). Similar distribution pattern was observed by Elbaz-Poulichet et al. (1994). As observed in figure 3, salinity is an important parameter in the distribution of $\mathrm{hDOCu}$. Indeed, in that 
area, dilution of continental water is a dominant factor for all determinands, and this can mask minor interactions or slow processes which are suggested by the dispersion of data as a function of salinity. The relationship between $\mathrm{hDOCu}$ and dissolved organic carbon reveals different behaviour, inside and outside the Rhone estuary (Fig. 4A). The slope (the ratio) of $\mathrm{hDOCu}$ on organic matter is remarkably larger in the estuarine water than in the coastal and sea waters.

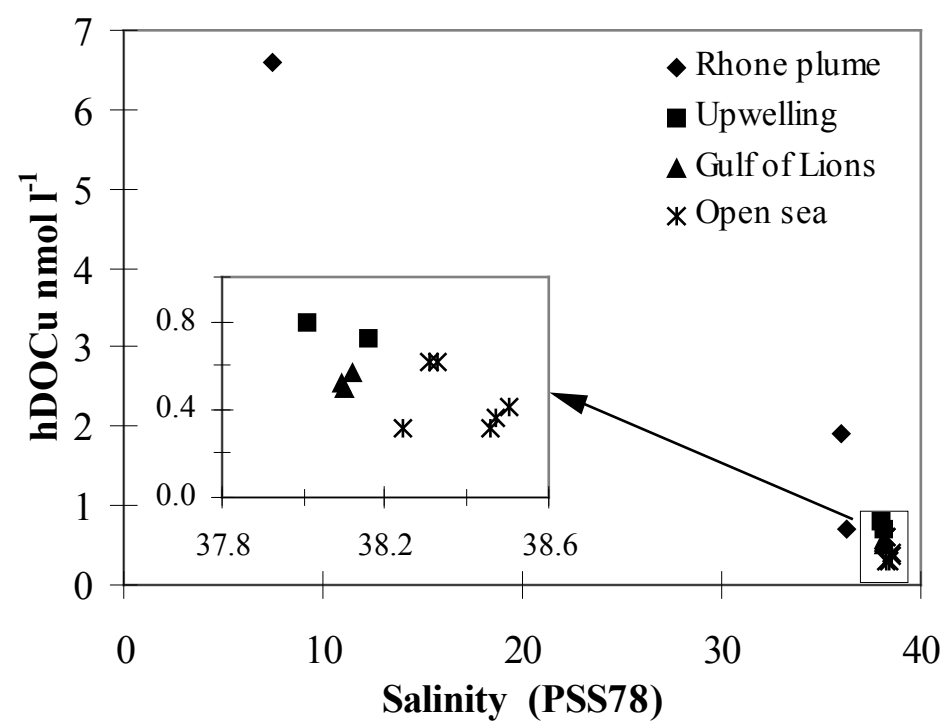

Figure 3. Hydrophobic dissolved organic copper (hDOCu) as a function of salinity in the northwestern Mediterranean.

The plot of dissolved $\mathrm{Cu}$ versus hDOCu shows an overall linear trend when all types of water are considered together (Fig. 4B). However, the fraction of TDCu present in the form of hDOCu shows a completely different relationship with TDCu in the coastal water than in the estuary (fig. 4C). In coastal water, the fraction of copper associated with hydrophobic organic matter decreases sharply with the increase of total dissolved copper concentration, while in the estuarine water the reverse trend is observed. Obviously several factors affect the concentration of $\mathrm{hDOCu}$.

It is well established that organic matter excreted by phytoplankton and its bacterial mineralization products have high complexing capacity for trace metals (Seritti et al., 1986; Kozarac et al., 1989; Zhou and Wangersky, 1989, Paulson et al., 1994b). It should also be pointed out that DOC has shown, out of the Rhone plume, a restricted range of concentration in surface water (0.7-0.8 $\mathrm{mg} \mathrm{l}^{-1}$; Aminot and Kérouel, 1990). This would indicate that variation of the $\mathrm{C} 18$ extractable copper in the area is related to the nature of organic matter rather than to its mass action influence. The strong increase of the percentage of organic copper at $50 \mathrm{~m}$ just below the thermocline in the open water (Fig. 2) tends to support this idea. Indeed, maximum phytoplankton production takes place just above the thermocline, in the warm, superficial layer as indicated by nutrients exhaustion (Minas, 1970; Coste et al., 1972; Cahet et al., 1972). ElbazPoulichet et al. (1994) related the subsurface hDOCu peak to the presence of biologically excreted organic matter of high copper affinity and the interference of colloidal and refractory organic matter produced by bacterial polymerization. 

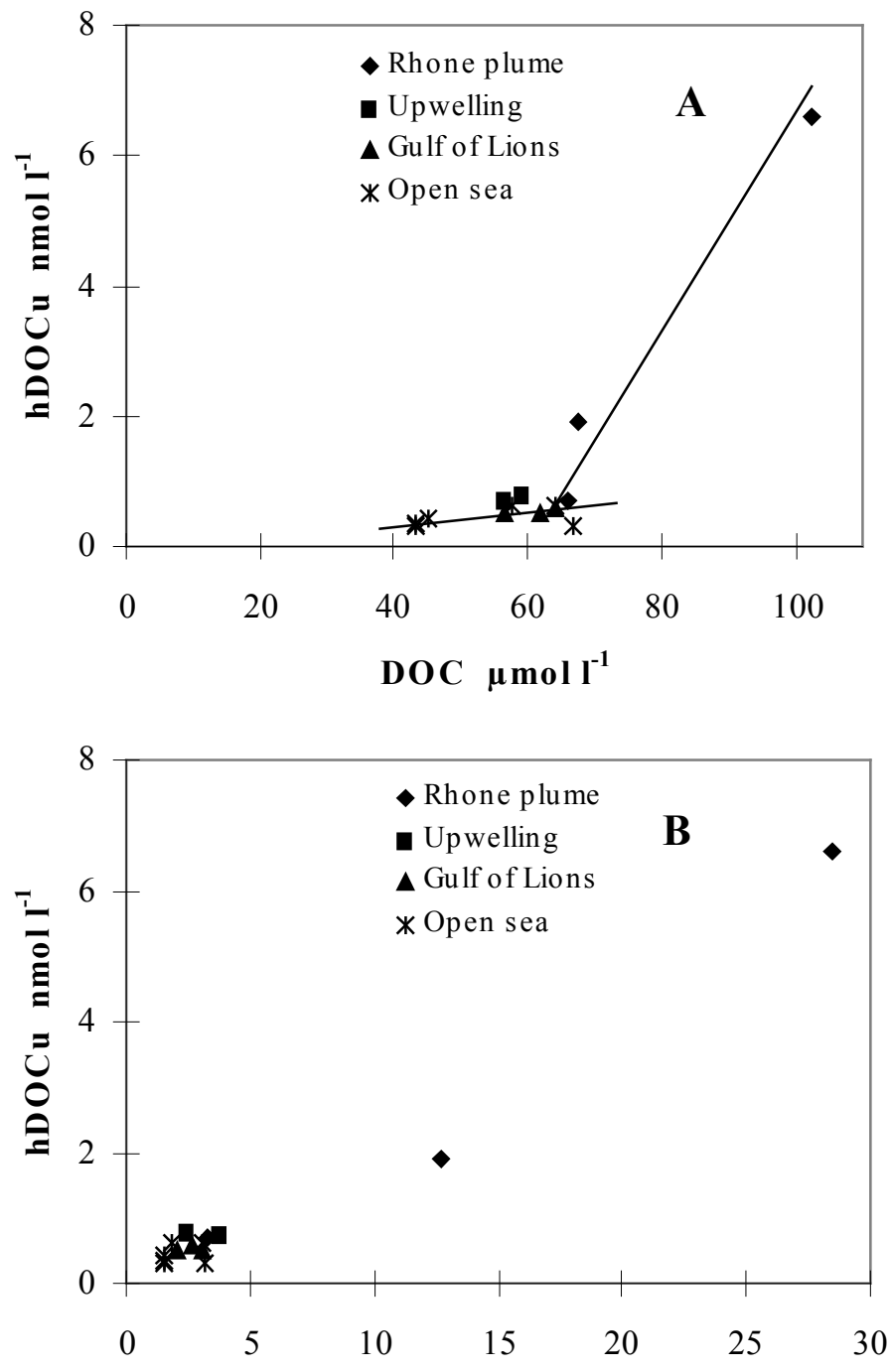

TDCu nmol I $\mathrm{I}^{-1}$

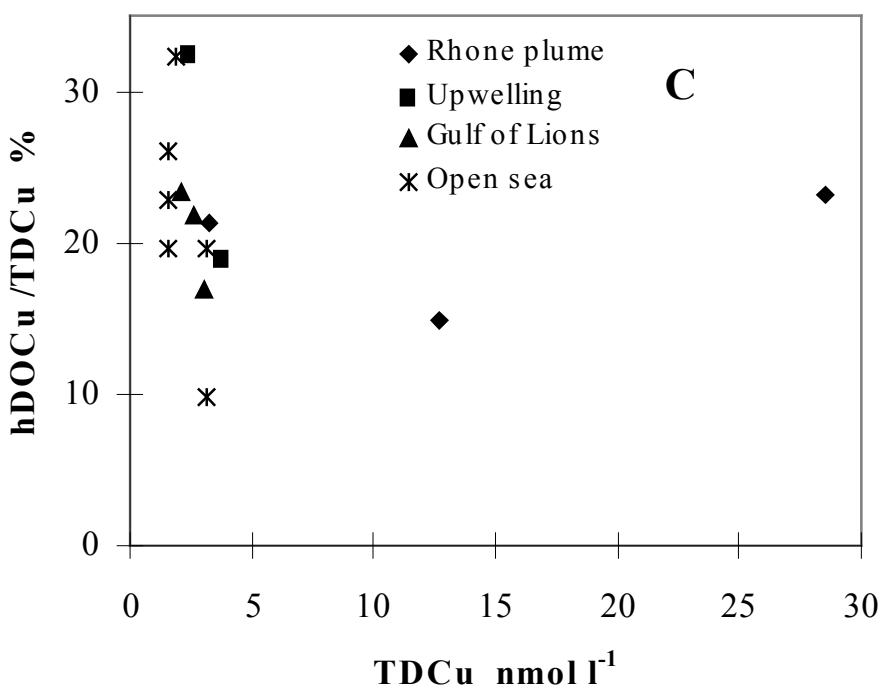

Figure 4. Hydrophobic dissolved organic copper (hDOCu) related to dissolved organic carbon (DOC) and total dissolved copper (TDCu). A and B: concentration. C: ratio hDOCu/TDCu. 
An experiment was therefore performed in order to check C18 SP extractability of DOM$\mathrm{Cu}$ complexes resulting from freshly produced algal organic matter. Approximately $175 \mathrm{~g}$ of a healthy specimen of the green algae Fucus vesiculosus $L$. were incubated for two weeks at $13{ }^{\circ} \mathrm{C}$ in 81 of filtered seawater from the Bay of Brest, under alternative $12 \mathrm{~h}$ dark/light, in order to enrich the water in fresh, highly complexing organic matter. The water was then filtered and extracted as described. The water sample, enriched in dissolved organic matter, contained $26.9 \mathrm{nmol} \mathrm{l}^{-1}$ as TDCu, $77 \%$ of which have been retained by the Sep-Pak cartridge as hDOCu. There is therefore no doubt that freshly produced algal organic matter is highly coppercomplexing and well recovered by Sep-Pak cartridges. This strongly supports the interest of the C18 SPE technique for study of the speciation of organic matter in water.

It is generally accepted that dissolved organic matter (DOM) could be regarded as composed of two major pools. One, recent and labile, results from biological excretion and its bacterial partial mineralization and polymerization while the second is older and refractory (Pomeroy, 1974; Menzel, 1974; Ogura, 1975; Bada and Lee, 1977). Based on this fact Donat et al. (1986) concluded that the labile fraction, expected to be found in the more productive surface waters and superimposed upon the pool of the older material that dominates in the deep and intermediate waters, might have higher complexing capacity. The work of Sunda and Hanson (1987) and Coale and Bruland (1988) suggests the presence of two complexing organic ligands $\mathrm{L}_{1}$ and $\mathrm{L}_{2}$ of high and low complexing capacity respectively, which supports the argument of Donat et al. (1986).

Therefore, interaction between copper and DOM may be expressed as the result of various equilibria involving ligands $\mathrm{L}_{1}, \mathrm{~L}_{2}, \mathrm{~L}_{\mathrm{i}}, \ldots \mathrm{L}_{\mathrm{n}}$. Assuming that each reaction is of the type:

$$
\mathrm{Cu}+\mathrm{L}_{\mathrm{i}} \Leftrightarrow \mathrm{CuL}_{\mathrm{i}} \text {, }
$$

with an equilibrium constant:

$$
\mathrm{K}_{\mathrm{i}}=\left(\mathrm{CuL}_{\mathrm{i}}\right) /(\mathrm{Cu})\left(\mathrm{L}_{\mathrm{i}}\right) \text {, }
$$

the concentration of dissolved organic copper is:

$$
(\mathrm{DOCu})=\Sigma\left(\mathrm{CuL}_{\mathrm{i}}\right), \quad \text { i.e. } \quad(\mathrm{DOCu})=(\mathrm{Cu})\left[\Sigma \mathrm{K}_{\mathrm{i}}\left(\mathrm{L}_{\mathrm{i}}\right)\right] .
$$

Consequently, it would result a complex relationship between dissolved organic tracers (DOC, DON, etc.) and DOCu (or any of its compound like $\mathrm{hDOCu}$ ), and no simple correlation should be observed between these parameters, even in the case of a two-ligand system.

In an attempt to assess hDOCu variations independently of both total dissolved copper and dissolved organic matter, concentrations of $\mathrm{hDOCu}$ have been " normalized " against these parameter, that is they are divided by TDCu and DOC as follows:

normalized $\mathrm{hDOCu}=\mathrm{hDOCu} /(\mathrm{DOC} \times \mathrm{TDCu})$.

In a defined volume, normalized $\mathrm{hDOCu}$ represents the number of mole of $\mathrm{hDOCu}$ per mole of DOC and per mole of TDCu, and therefore, this parameter can be considered as reflecting the complexing capacity $(\mathrm{CC})$ of the hydrophobic organic matter. When this parameter is plotted against salinity, a consistent relationship can be obtained (Fig. 5). From this graph, the following conclusions can be drawn.

a) The Rhone water exhibits a rather low $\mathrm{CC}$ which is in accordance with the idea that marine organic matter has higher complexing capacity than land derived organic matter.

b) $\mathrm{CC}$ increases slightly in the river plume towards a salinity of 36 , then sharply between salinity 36 and 38. The latter salinity range corresponds to the less turbid part of the Rhone plume, still enriched in nutrients (El Sayed et al., 1994), where productivity reaches its maximum in the Gulf. Therefore, contribution of fresh and highly complexing organic ligands to the dissolved organic matter pool would be relatively elevated.

c) In the superficial water of the Gulf, CC behaviour also seems to be related to productivity. Salinity increase, which means decrease of nutrients concentration and lowering of productivity, is accompanied by a sharp decrease of the $\mathrm{CC}$ value. The lowest $\mathrm{CC}$ is logically measured in the open sea surface water. 


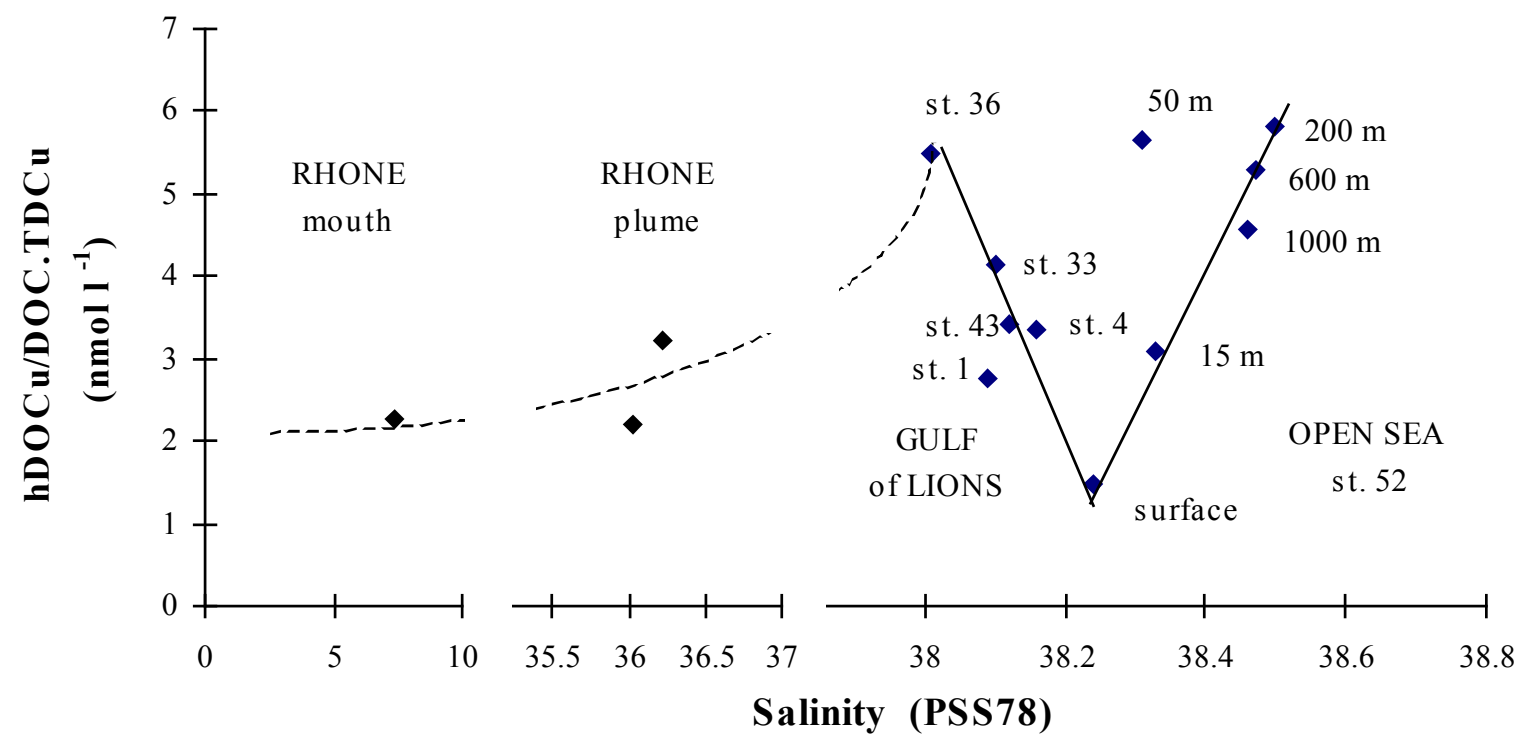

Figure 5. Relationship between salinity and normalized hDOCu in the northwestern Mediterranean. "Normalized hDOCu" reflects the complexing power of the hydrophobic organic matter in relation to dissolved copper.

d) At the open sea station, CC shows an opposite behaviour compared with surface waters, i.e. an increase of $\mathrm{CC}$ with increasing salinity, with the exception of the $50 \mathrm{~m}$ layer. Deep waters, in which DOM is obviously much older than in surface water, exhibits CC which are comparable with those of the productive areas. This may result from the process of ageing and humification, which would mean that sites with low complexing capacity are progressively eliminated. Finally, the maximum CC observed at $50 \mathrm{~m}$ depth is consistent with the high productivity at that level, as already mentioned.

\section{CONCLUSION}

Experimental study emphasized that in most natural waters separation of hydrophobic dissolved organic copper using the C18 Sep-Pak extraction technique might be achieved without appreciable interference of the inorganic copper species. Field application in the conditions encountered in the Mediterranean was therefore valid.

From the field study, it has been possible to show that interaction of DOM and copper could not be described using simple relationships with other hydrochemical parameters.

Normalization of the $\mathrm{hDOCu}$ data using both DOC and TDCu lead to a consistent interpretation of the data by introducing the notion of complexing capacity of DOM. However, contrary to the classical assertion that fresh DOM should exhibit a greater complexing capacity than old DOM, we found that both can exhibit comparable complexing capacity for copper. In the Mediterranean water, relatively high CC were found in productive superficial and intermediate waters and deep water layers. The consistency of the results of the field experiments confirms the validity of the Sep-Pak technique for the study of organically-bound metals in seawater.

\section{ACKNOWLEDGEMENT}

The authors are grateful to Roger Kérouel, IFREMER-Brest, for performing nutrients and dissolved organic carbon determinations. 


\section{REFERENCES}

Aminot, A., El Sayed, M.A. \& Kérouel, R., 1990. Fate of natural and anthropogenic dissolved organic carbon in the macrotidal Elorn Estuary (France). Marine Chemistry 29, 255275.

Aminot, A. \& Kérouel, R., 1990. Improvement of a commercial continuous flow method for the determination of dissolved organic carbon in fresh and seawater. Analusis 18, 289-295.

Bada, J.L. \& Lee, C., 1977. Decomposition and alteration of organic-compounds dissolved in seawater. Marine Chemistry 5, 523-534.

Boyle, E.A., Sclater, F.R. \& Edmond, J.M., 1977. The distribution of dissolved Cu in the Pacific. Earth and Planetary Science Letters 37, 38-54.

Bruland, K.W., 1989. Complexation of zinc by natural organic ligands in the central North Pacific. Marine Chemistry, 29, 221-223.

Cahet, G., Fiala, M., Jacques, G. \& Panouse, M., 1972. Production primaire au niveau de la thermocline en zone néritique de Méditerranée nord-occidentale. Marine Biology 14, 32-40.

Coale, K.H. \& Bruland, K.W., 1988. Copper complexation in the northeast Pacific. Limnology \& Oceanography 33, 1084-1101.

Coste, B., Gostan, J. \& Minas, H.J., 1972. Influence des conditions hivernales sur les productions phyto- et zooplanktoniques en Mediterranée nord-occidentale. I. Structures hydrologiques et distribution des sels nutritifs. Marine Biology 16, 320-348.

Donat, J.R., Statham, P.J. \& Bruland, K.W., 1986. An evaluation technique for isolating metal-organic complexes from Central North Pacific Ocean waters. Marine Chemistry 18, 85-89.

Elbaz-Poulichet, F., Cauwet, G., Guan, D.M., Faguet, D., Barlow, R. \& Mantoura, R.F.C., 1994. C18 Sep-Pak extractable trace metals in waters from the Gulf of Lions. Marine Chemistry 46, 67-75.

El Sayed, M.A. 1988. Contribution à l'étude du comportement géochimique de quelques métaux traces ( cuivre, fer, manganèse et zinc) et de la matière organique dans le milieu estuarien. Cas de l'estuaire de la Loire et de la rade de Brest. Thèse d'Etat, Université de Bretagne Occidentale, Brest, France, 472 pp.

El Sayed, M.A., Aminot, A. \& Kérouel, R. 1994. Nutrients and trace metals in the northwestern Mediterranean. Continental Shelf Research 14, 507-530.

Hanson, A.K., 1981. The distribution and biogeochemical cycling of transition metal organic complexes in the marine environment. Ph.D. Thesis. Univ. Rhode Island, Kingston, RI., 174 pp.

Hanson, A.K. \& Quinn J.G., 1983. The distribution of dissolved and organically complexed copper and nickel in the middle Atlantic Bight. Canadian Journal of Fisheries \& Aquatic Sciences 40 (Suppl. 2), 151-161.

Hirose, K., Dokoya, Y. \& Sugimura, Y. 1982. Determination of conditional stability constants of organic copper and zinc complexes dissolved in seawater using ligand exchange method with EDTA. Marine Chemistry 11, 343-353.

Jeffrey, L.M., 1970. Lipids of marine waters, in: Hood, D.W. (Ed), Symposium on organic matter in natural waters, Institute of Marine Sciences of Alaska pp. 55-76.

Kerr, R.A. \& Quinn, J.G., 1980. Chemical comparison of dissolved organic matter isolated from different oceanic environments. Marine Chemistry 13, 169-180.

Kingston, H.M., Barnes, I.L., Rains, T.C. \& Champ, M.A., 1978. Separation of eight transition elements from alkali and alkaline earth elements in estuarine and seawater with chelating resin and their determination by graphfurnace atomic absorption spectrometry. Analytical Chemistry 50, 2064-2070. 
Kozarac, Z., Plavsic, M. \& Cosovic, B., 1989. Interactions of cadmium and copper with surface active organic matter and complexing ligands released by marine phytoplankton. Marine Chemistry 26, 313-330.

Kremling, K., Wenck, A. \& Osterroht C., 1981. Investigation on dissolved copperorganic substances in Baltic waters. Marine Chemistry 10, 209-219.

Mackey, D.J., 1983. The strong complexing capacity of seawater - An investigation of south-eastern Australian coastal waters. Marine Chemistry 14, 73-87.

Mackey, D.J., 1984. An investigation of metal-organics in seawater using HPLC with atomic fluorescence detection, in: C.J.M. Kramer \& J.C. Duinker (Eds), Complexation of trace metals in natural water, Martinus Nijhoff and W. Junk, The Hague, pp 55-65.

Mackey, D.J. 1985. HPLC analyses of metal-organics in seawater - Interference effects attributed to stationary-phase free silanols. Marine Chemistry 16, 105-119.

Menzel, D.W., 1974. Primary productivity, dissolved organic matter, and the sites of oxidation of organic matter, in: E.D. Goldberg (Ed), The sea (Vol. 5), Wiley Interscience, pp 659-678.

Mills, G.L. \& Quinn, J.G., 1981. Isolation of dissolved organic matter and copper organic complexes from estuarine waters using reverse-phase liquid chromatography. Marine Chemistry 10, 93-102.

Mills, G.L., Hanson, A.K., Quinn, J.G., Lamell, W.R. \& Chasteen, N.D., 1982. Chemical studies of copper-organic complexes from estuarine waters using $\mathrm{C} 18$ reversephase liquid chromatography. Marine Chemistry 11, 355-377.

Mills, G.L., McFadden, E. \& Quinn, J.G., 1987. Chromatographic studies of dissolved organic matter and copper-organic complexes isolated from estuarine waters. Marine Chemistry 20, 277-288.

Mills, G.L., Douglas, G.S. \& Quinn, J.G., 1989. Dissolved organic copper isolated by C18 reverse phase extraction in an anoxic basin located in the Pettaquamscutt river estuary. Marine Chemistry 26, 277-288.

Minas, H.J., 1970. La distribution de l'oxygène en relation avec la production primaire en Méditerranée Nord-Occidentale. Marine Biology 7, 181-204.

Ogura, N., 1975. Further studies on decomposition of dissolved organic matter in coastal seawater. Marine Biology 13, 101-111.

Pomeroy, L.R. 1974. The oceans food web, a changing paradigm. Bioscience 24, 499504.

Paulson, A.J., 1991. Cu interactions between dissolved and particulate organic matter in estuarine waters. Ph.D. Univ. Washington, Seattle, WA, 252 pp.

Paulson, A.J., Curl, Jr. H.C. \& Gendron, J.F., 1994a. Partitioning of $\mathrm{Cu}$ in estuarine waters, I. Partitioning in a poisoned system. Marine Chemistry 454, 67-80.

Paulson, A.J., Curl, Jr., H.C. \& Gendron, J.F., 1994b. Partitioning of Cu in estuarine waters, II. Control of partitioning by the biota. Marine Chemistry 45, 81-93.

Seritti, A., Pellegrini, D. Morelli, E., Barghani, C. \& Ferrara, R., 1986. Copper complexing capacity of phytoplanktonic cell exudates. Marine Chemistry 18, 351-357.

Sunda, W.G. \& Hanson, A.K., 1987. Measurement of free cupric ion in seawater by a ligand competition technique involving copper sorption onto $\mathrm{C}_{18}$ Sep-Pak cartridges. Limnology \& Oceanography 32 (3), 537-551.

Van den Berg, C.M.G., 1984. Determination of complexing capacitiy and conditional stability constants of complexes of copper (II) in sea water by cathodic stripping voltametry of copper-catechol complexes. Marine Chemistry 14, 201-212.

Zhou, X. \& Wangersky, P., 1989. Production of copper complexing organic ligands by the marine diatom Phaeodactylum tricornutum in a cage culture turbidostat. Marine Chemistry 26, 239-259. 